\title{
REVIEW ARTICLE Positron emission tomography of type 2 cannabinoid receptors for detecting inflammation in the central nervous system
}

\author{
Ruiqing $\mathrm{Ni}^{1}$, Linjing $\mathrm{Mu}^{1,2}$ and Simon Ametamey ${ }^{1}$
}

\begin{abstract}
Cannabinoid receptor $\mathrm{CB}_{2}\left(\mathrm{CB}_{2} \mathrm{R}\right)$ is upregulated on activated microglia and astrocytes in the brain under inflammatory conditions and plays important roles in many neurological diseases, such as Alzheimer's disease, amyotrophic lateral sclerosis, and ischemic stroke. The advent of positron emission tomography (PET) using $C_{2} R$ radiotracers has enabled the visualization of $C B_{2} R$ distribution in vivo in animal models of central nervous system inflammation, however translation to humans has been less successful. Several novel $C_{2} R$ radiotracers have been developed and evaluated to quantify microglial activation. In this review, we summarize the recent preclinical and clinical imaging results of $C B_{2} R$ PET tracers and discuss the prospects of $C B_{2} R$ imaging using $P E T$.
\end{abstract}

Keywords: cannabinoid receptor CB2; microglia; inflammation; neurological diseases; positron emission tomography

Acta Pharmacologica Sinica (2019) 40:351-357; https://doi.org/10.1038/s41401-018-0035-5

\section{CANNABINOID RECEPTOR CB ${ }_{2} R$}

Cannabinoid receptors, including $\mathrm{CB}_{1} \mathrm{R}$ and $\mathrm{CB}_{2} \mathrm{R}$ subtypes, are $\mathrm{G}$ protein-coupled receptors that are involved in endocannabinoid signaling and various physiological processes, such as pain, mood, and memory [1]. $C B_{1} R$ is expressed abundantly in the central nervous system (CNS), whereas $C_{2} R$ exists mainly in the peripheral organs (e.g., spleen) and is undetectable in the brain under physiological conditions. In the periphery, $C_{2} B_{2} R$ is expressed on leukocytes and macrophages and regulates inflammation and immune functions, such as phagocytosis inhibition, $B$ and $T$ cell differentiation, and the balance of pro-inflammatory/anti-inflammatory cytokines. Under CNS inflammation, $\mathrm{CB}_{2} \mathrm{R}$ expression is upregulated on microglia, astrocytes, and oligodendrocytes and on post-synaptic neurons [2] in the hippocampus, brainstem, and cerebellum of both mouse/rat models [1, 3-5] and humans [6]. $\mathrm{CB}_{2} \mathrm{R}$ has mainly been associated with anti-inflammatory/immunosuppressive roles and reductions in nuclear factor NF-KB and inflammatory mediators. Its low baseline expression and diseaseinduced increase make $\mathrm{CB}_{2} \mathrm{R}$ a promising diagnostic and therapeutic target for CNS inflammation.

Microglia and astrocytes are major players in the brain innate immune system. They are morphologically dynamic and undergo priming based on the local context [7]. Ramified microglia are activated in response to brain injury and immune stimuli and develop a "classical activation, pro-inflammation" status or an "alternative activation, anti-inflammation" status [8]. The extent to which inflammation is beneficial or detrimental in disease processes has not been fully elucidated. Acute inflammation consists of an immediate and early response to a stimulus, such as stroke or trauma, and a subsequent defensive response that facilitates repair. Chronic CNS inflammation resulting from persistent stimuli is an important component in the pathophysiology of many neurological diseases, such as Alzheimer's disease
(AD), Parkinson's disease [9], amyotrophic lateral sclerosis (ALS) [10], multiple sclerosis (MS) [11], and Huntington disease [12].

\section{CNS INFLAMMATION TRACERS}

Positron emission tomography (PET) enables the in vivo detection of molecular changes in animal models and in humans, thus facilitating the understanding of disease mechanisms. The development of CNS inflammation tracers has been challenging, partly due to the diverse and changing states of astrocytes and microglia. Tracers for translocator protein (TSPO) have been the most applied probes in studying the microglial activation status in patients with neurological disorders $[13,14]$. Several TSPO tracers have been evaluated in animal models and patients, including the first-generation $\left[{ }^{11} \mathrm{C}\right] \mathrm{PK} 11195$, second-generation molecules such as $\left[{ }^{11} \mathrm{C}\right] \mathrm{DAA} 1106,\left[{ }^{11} \mathrm{C}\right] \mathrm{PBR} 28$, and [ $\left.{ }^{18} \mathrm{~F}\right] \mathrm{DPA}-714$ [15], and thirdgeneration rs6971-insensitive radiotracers such as $\left[{ }^{11} \mathrm{C}\right]$ ER176 [16] and $\left[{ }^{18} \mathrm{~F}\right] \mathrm{GE} 180[17,18]$. Although it has had varying degrees of utility in different neurological diseases, TSPO imaging has the limitations of specificity of binding, data quantification (reference region), and mixed binders of the second-generation tracers due to the polymorphism in the TSPO gene $[14,19]$. New classes of tracers detecting, e.g., $\mathrm{CB}_{2} \mathrm{R}$, monoamine oxidase $\mathrm{B}$ [20] cyclooxygenases $(\operatorname{COX} 1,2)$, and arachidonic acid [17, 21], are under development as potential tracers for CNS inflammation.

\section{PET TRACERS FOR IMAGING $\mathbf{C B}_{\mathbf{2}} \mathbf{R}$}

Several $C B_{2} R$ tracers have been developed, including the oxoquinoline derivatives $\left[{ }^{11} \mathrm{C}\right] \mathrm{KD} 2[22],\left[{ }^{11} \mathrm{C}\right] \mathrm{KP} 23[23],\left[{ }^{11} \mathrm{C}\right] \mathrm{RS}-$ $016[24,25],\left[{ }^{11} \mathrm{C}\right] \mathrm{RSR}-056[26],\left[{ }^{11} \mathrm{C}\right] \mathrm{RS}-028$, and $\left[{ }^{18} \mathrm{~F}\right] \mathrm{RS}-126$ $[22,25-31]$, and $\left[{ }^{11} \mathrm{C}\right] \mathrm{NE} 40$ [32]; and the thiazole derivatives $\left[{ }^{11} \mathrm{C}\right]$ A-836339 [33, 34], $\left[{ }^{18} \mathrm{~F}\right] J H U 94620[35,36]$, and $\left[{ }^{18} \mathrm{~F}\right] 2 \mathrm{f}[37]$. They

\footnotetext{
'Department of Chemistry and Applied Biosciences, Center for Radiopharmaceutical Sciences of ETH-PSI-USZ, Institute of Pharmaceutical Sciences, ETH Zurich, Zurich 8093, Switzerland and ${ }^{2}$ Department of Nuclear Medicine, University Hospital Zurich, Zurich 8091, Switzerland

Correspondence: Ruiqing Ni (ni@biomed.ee.ethz.ch)
}

Received: 25 December 2017 Accepted: 1 May 2018

Published online: 19 June 2018 
Table 1. Summary of $\mathrm{CB}_{2} \mathrm{R}$ tracer properties

\begin{tabular}{|c|c|c|c|c|c|c|c|}
\hline Class & Tracer & $\begin{array}{l}\text { Affinity } \\
\mathrm{hCB}_{2} \mathrm{R}\end{array}$ & $\begin{array}{l}\text { Selectivity } \\
\mathrm{CB}_{1} \mathrm{R}\end{array}$ & LogP & Human & Animal model & Ref \\
\hline \multirow[t]{3}{*}{ Thiazole } & {$\left[{ }^{11} \mathrm{C}\right] \mathrm{A}-836339$} & $0.64 \mathrm{nM}$ & $>400$ & 2.97 & & $\begin{array}{l}\text { AD mouse model; stroke, LPS, } \\
\text { AMPA injected rat model }\end{array}$ & {$[33,34]$} \\
\hline & {$\left[{ }^{18} \mathrm{~F}\right] 2 \mathrm{f}$} & $0.1 \mathrm{nM}$ & $>300$ & 3.4 & & $\begin{array}{l}\text { Healthy Wistar rat LPS-injected } \\
\text { CD1 mouse }\end{array}$ & [41] \\
\hline & {$\left[{ }^{18} \mathrm{~F}\right] J H U 94620$} & $0.38 \mathrm{nM}$ & 1000 & & & & {$[35,36]$} \\
\hline & {$\left[{ }^{11} \mathrm{C}\right] \mathrm{RSR}-056$} & $2.5 \mathrm{nM}$ & $>1000$ & 1.94 & $\begin{array}{l}\text { Post-mortem AD brain, } \\
\text { ALS spinal cord }\end{array}$ & LPS-injected mouse & [26] \\
\hline & {$\left[{ }^{11} \mathrm{C}\right] \mathrm{RS}-016$} & $0.7 \mathrm{nM}$ & $>1000$ & 2.78 & & & {$[25,30]$} \\
\hline & {$\left[{ }^{11} \mathrm{C}\right] \mathrm{KD} 2$} & & & & & & [22] \\
\hline & {$\left[{ }^{11} \mathrm{C}\right] \mathrm{KP} 23$} & & & & & & \\
\hline & {$\left[{ }^{11} \mathrm{C}\right] 6 \mathrm{~b}$} & $9.4 \mathrm{nM}$ & 1067 & & & & \\
\hline \multirow[t]{2}{*}{ Indole } & {$\left[{ }^{18} \mathrm{~F}\right] \mathrm{FE}-\mathrm{GW} 405833$} & $27 \mathrm{nM}$ & 6000 & 2.5 & & & [50] \\
\hline & $\begin{array}{l}{\left[{ }^{11} \mathrm{C}\right] \text { Methoxy- }} \\
\text { Sch225336 }\end{array}$ & $4.5 \mathrm{nM}$ & 78 & 2.15 & & & [51] \\
\hline \multirow[t]{2}{*}{ Oxadiazole } & {$\left[{ }^{11} \mathrm{C}\right] \mathrm{MA} 2$} & $87 \mathrm{nM}$ & 19 & & & NMRI mouse & [38] \\
\hline & {$\left[{ }^{18} \mathrm{~F}\right] \mathrm{MA3}$} & $0.8 \mathrm{nM}$ & 127 & & & & \\
\hline \multirow[t]{3}{*}{ Thiophene } & {$\left[{ }^{11} \mathrm{C}\right] \mathrm{AAT}-015$} & $3.3 \mathrm{nM}$ & 303 & 4.11 & & Rat & [29] \\
\hline & {$\left[{ }^{11} \mathrm{C}\right] \mathrm{AAT}-778$} & $4.3 \mathrm{nM}$ & 256 & 6 & & & \\
\hline & {$\left[{ }^{18} \mathrm{~F}\right] \mathrm{FC} 0324$} & $0.1 \mathrm{nM}$ & 296 & & & Rat & [39] \\
\hline Amid & {$\left[{ }^{18} \mathrm{~F}\right] 1,2$} & $2.3 \mathrm{nM}$ & $>500$ & & & CD1 mouse & [52] \\
\hline
\end{tabular}

have shown high-affinity binding to $\mathrm{CB}_{2} \mathrm{R}$ and sufficient selectivity over $\mathrm{CB}_{1} \mathrm{R}$. The oxadiazole derivatives $\left[{ }^{11} \mathrm{C}\right] \mathrm{MA} 2$ and $\left[{ }^{18} \mathrm{~F}\right] \mathrm{MA} 3[38]$ and thiophene-based tracers $\left[{ }^{11} \mathrm{C}\right]$ AAT-778, $\left[{ }^{11} \mathrm{C}\right]$ AAT-015 [29], and $\left[{ }^{18} \mathrm{~F}\right] \mathrm{FC0324}$ [39] show high affinity to $\mathrm{CB}_{2} \mathrm{R}$ but suboptimal selectivity over $C B_{1} R$. Table 1 summarizes the relevant properties of the $C_{2} R$ radiotracers. Figure 1 shows the chemical structures of different classes of $\mathrm{CB}_{2} \mathrm{R}$ tracers. For the structure-activity relationships of $\mathrm{CB}_{2} \mathrm{R}$ tracers, see the recent review published by Spinelli et al. [40]. Some of the most important prerequisites for a useful CNS PET tracer for imaging $C_{2} R$ include: (1) highnanomolar-affinity binding to $\mathrm{CB}_{2} \mathrm{R}$ to obtain a high target signal in vivo $\left(\mathrm{BP}_{\mathrm{nd}}\right.$ or \% ID/g) given the low concentration of $\mathrm{CB}_{2} \mathrm{R}$ in the brain; (2) suitable LogP (range 1-3) for blood-brain barrier passage; (3) specific binding to $\mathrm{CB}_{2} \mathrm{R}$ with 1000 -fold higher selectivity over $\mathrm{CB}_{1} \mathrm{R}$; (4) no radiometabolites in the brain; and (5) low interaction with plasma proteins. This review focuses on the evaluations of $\mathrm{CB}_{2} \mathrm{R}$ tracers in animal models and patients with neurological diseases involving CNS inflammation.

\section{CB $_{2}$ IMAGING IN ANIMAL MODELS}

Spleen tissue, which is rich in $C B_{2} R$, obtained from animals has been used to evaluate the specificity of $C_{2} R$ tracers. Several $C B_{2} R$ tracers bind with high specificity in spleen tissue slices. Figure $2 a, c$ show autoradiograms showing the specific binding using the PET tracers $\left[{ }^{11} \mathrm{C}\right] \mathrm{RSR}-056$ and $\left[{ }^{18} \mathrm{~F}\right] \mathrm{RS}-126$. The accumulation of $\left[{ }^{11} \mathrm{C}\right]$ RSR-056 and $\left[{ }^{18} \mathrm{~F}\right] \mathrm{RS}-126$ was blocked with the $\mathrm{CB}_{2} \mathrm{R}$ antagonist GW405833 in spleen slices obtained from a CD1 mouse and a Wistar rat. Different animal models have been used for the in vivo evaluation of $\mathrm{CB}_{2} \mathrm{R}$ tracers using PET imaging: (1) mouse and rat models with local human $\mathrm{CB}_{2} \mathrm{R}$ overexpression, as well as rhesus monkey [42] and (2) lipopolysaccharide (LPS)-injected mice and rats. The uptake of $\mathrm{CB}_{2} \mathrm{R}$ tracer in the brain is rather low, with a \% $\mathrm{ID} / \mathrm{g}$ of $0.1-0.4$ at $1 \mathrm{~h}[33,42]$ and a binding potential of $1.4-3$ in animal models. Figure 3 shows the coronal view of $\left[{ }^{11} \mathrm{C}\right] \mathrm{RSR}-056-$ PET overlaid on structural magnetic resonance imaging, demonstrating higher radioactivity retention in the cortex and hippocampus of an LPS-injected mouse (b) compared to a vehicleinjected mouse (a) and an LPS-injected + GW405833-treated mouse (c). The PET images were generated from averaged dynamic data at 20-60 min after the intravenous injection of $\left[{ }^{11} \mathrm{C}\right] \mathrm{RSR}-056$. The upregulation of $\mathrm{CB}_{2} \mathrm{R}$ detected by using $\left[{ }^{11} \mathrm{C}\right]$ RSR-056 appeared to be global instead of local, which might have been related to the specificity of the radiotracer. The results from a PET study using $\left[{ }^{11} \mathrm{C}\right] \mathrm{A}-836339$ showed no specific uptake in the rat brain intrastriatally injected with LPS and a-amino-3-hydroxy-5methyl-4-isoxazolepropionic acid [34], although immunostaining for $\mathrm{CB}_{2} \mathrm{R}$ showed positive signals. Another PET study using $\left[{ }^{18} \mathrm{~F}\right] \mathrm{RS}-$ $126[28]$ or $\left[{ }^{18} \mathrm{~F}\right] \mathrm{JHU} 94620[35,36]$ showed specific uptake in the $\mathrm{CB}_{2} \mathrm{R}$-rich spleen, but not sufficient signals in the brain, of LPStreated mice. LPS-injected models have been used to represent a pro-inflammatory rather than anti-inflammatory state. Thus, they might not be the most suitable for evaluating of $C_{2} R$.

$\mathrm{CB}_{2} \mathrm{R}$ imaging in an animal model of stroke Ischemic stroke involves a cascade of hemodynamic, vascular, structural, and inflammatory responses in a time-dependent manner [54-56]. Inflammation is implicated in the initial neuronal loss and consists mainly of pro-inflammatory responses and the extension of the lesion in the penumbra; the subsequent 


\section{Oxoquinoline}

$\left[{ }^{11} \mathrm{C}\right] \mathrm{NE} 40$<smiles>CCCCCOc1ccc2cc(C(=O)NC3CCCCC3)c(=O)[nH]c2c1OCCCCCCCCO</smiles><smiles>CCOC(=O)C(CC)(CC)NC(=O)c1ccc(N2CC(O[14CH3])C2)c(OCC2CC2)n1</smiles><smiles>Cc1sc(=NC(=O)C2C(C)(C)C2(C)C)n(CCO[Ga])c1C</smiles>

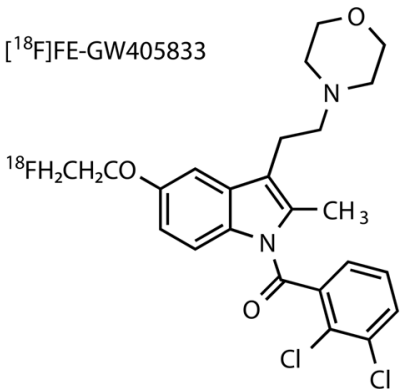

$\left[{ }^{18} \mathrm{~F}\right] \mathrm{RS}-126$<smiles>COc1cccc2c(=O)c(C(=O)NC34CC5CC(CC(C5)C3)C4)cn(CCOCC[18F])c12</smiles><smiles>CCc1c(C(=O)NC23CC4CC(CC(C4)C2)C3)nc(COC=CC(C)[Y17](F)(F)F)n1-c1ccccc1</smiles><smiles>CCOCCn1cc(C(=O)NC23CC4CC(CC(C4)C2)C3)c(=O)c2cccc(O[13CH3])c21</smiles><smiles>CCCCCn1cc(C(=O)NC23CC4CC(CC(C4)C2)C3)c(=O)c2cccc(O[AlH2])c21</smiles><smiles>Cc1s/c(=N\C(=O)C2C(C)(C)C2(C)C)n(CCCC[18F])c1C</smiles>

\section{Oxadiazole}<smiles>COc1ccc2ncc(NCCCc3nc(-c4ccc(F)cc4Cl)no3)cc2c1</smiles><smiles>F/C=C\CCCC(F)F</smiles><smiles>CCCOc1ccc2ncc(NCCCc3nc(-c4ccc(F)cc4Cl)no3)cc2c1</smiles>

Fig. 1 Chemical structures of $\mathrm{CB}_{2} \mathrm{R}$ tracers of oxoquinoline, thiazole, oxadiazole, and thiophene-based derivatives

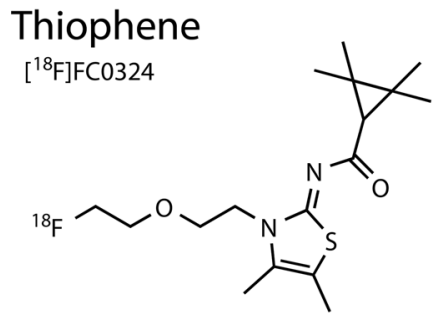

functional recovery involves anti-inflammatory responses. Upregulated $C_{2} R$ mRNA was reported in a mouse focal ischemia model, peaking at 5 days and returning to normal at 10 days after occlusion [54]. Treatment with $\mathrm{CB}_{2} \mathrm{R}$ agonists has neuroprotective effects and attenuates macrophage/microglial activation in ischemic mouse models [54, 56-59].

The models of $\mathrm{CB}_{2} \mathrm{R}$ imaging in ischemic stroke animal have been inconclusive. An increased $\left[{ }^{11} \mathrm{C}\right] \mathrm{NE} 40$ binding with no change in the binding of TSPO tracer $\left[{ }^{11} \mathrm{C}\right] \mathrm{PK} 11195$ [43] was reported in an SD rat model of photothrombotic stroke at $24 \mathrm{~h}$ after surgery. Another study using $\left[{ }^{11} \mathrm{C}\right] \mathrm{NE} 40$ imaging did not show an upregulated signal in a Wistar rat model of photothrombotic stroke [48], despite the minor increase in the level of $\mathrm{CB}_{2} \mathrm{R}$ seen by immunostaining. Low $\left[{ }^{11} \mathrm{C}\right] \mathrm{A}-836339$ uptake was detected in a rat model over 1-28 days after occlusion, despite positive immunostaining for $\mathrm{CB}_{2} \mathrm{R}$ and $\mathrm{CD} 11$ (markers for microglial activation) [34]. The utility of animal models of cerebral ischemia has been demonstrated in previous studies using TSPO tracers. Possible reasons for the different observations include the time point of assessment and differences between the stroke models. Different methods for inducing acute stroke (transient or permanent ischemia) result in variations in size, the severity of the ischemic regions, and the expression of inflammatory markers [56]. Since the pathophysiology and inflammatory levels and types evolve during the course of ischemic stroke, it is critical to reduce variations and make assessments at the optimal times. $A s C_{2} R$ are mostly associated with anti-inflammation, performing imaging, flow cytometry, and mRNA measurements at a subacute window 4-5 days after ischemia might be suitable [54].

$\mathrm{CB}_{2} \mathrm{R}$ imaging in animal models of Alzheimer's disease $A D$ is the most common neurodegenerative disease. The abnormal accumulation of amyloid-beta $(A \beta)$ and tau aggregates leads to a cascade of pathophysiological changes, including inflammation, microvascular alternations, synaptic dysfunction, and neuronal loss. Microglia play a phagocytic role in the clearance of pathological protein deposits [60] and act as proinflammatory agents $[61,62]$. Treatment with $\mathrm{CB}_{2} \mathrm{R}$ agonists in $\mathrm{AD}$ mouse models reverses $A \beta$-induced memory impairment [63]. MicroPET using $\left[{ }^{11} \mathrm{C}\right] \mathrm{A}-836339$ showed specific uptake in the brain areas with $A \beta$ depositions in an APPswe/PS1dE9 mouse model of $A D$ [33]. PET studies in some other AD mouse models using $\left[{ }^{11} \mathrm{C}\right]$ deprenyl in APPswe mice [20] and TSPO tracer $\left[{ }^{18} \mathrm{~F}\right] \mathrm{GE} 180$ in APP23 mice suggested increased astrocytosis and microgliosis at early disease stages. However, as age-related inflammation is also a confounding factor for the relatively mild inflammation in $A D$ mouse models, these models might not be ideal for evaluating $\mathrm{CB}_{2} \mathrm{R}$ tracers. 


\section{a $\left[{ }^{11} \mathrm{C}\right] \mathrm{RSR}-056$ in mouse spleen}

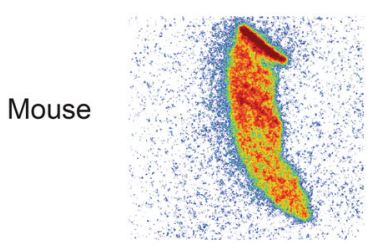

Baseline

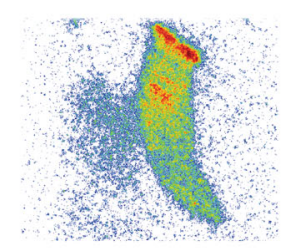

Blockage (GW405833)

C $\left[{ }^{18} \mathrm{~F}\right] \mathrm{RS}-126$ in rat spleen

Rat

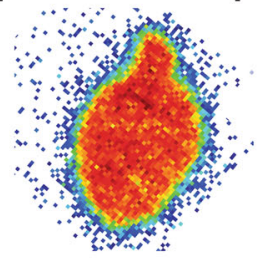

Baseline

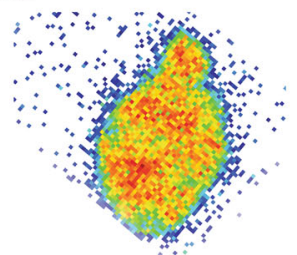

Blockage (GW405833)

\section{b $\left[{ }^{11} \mathrm{C}\right] \mathrm{RSR}-056$ in ALS spinal cord}

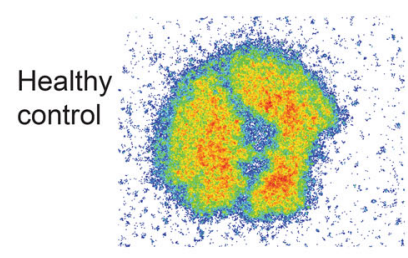

Baseline

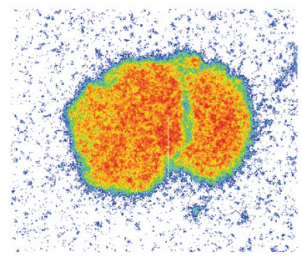

Baseline

\section{ALS}

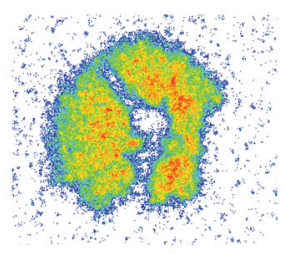

Blockage (GW405833)

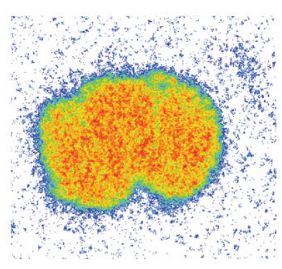

Blockage (GW405833)

Fig. 2 Representative in vitro autoradiograms of $\mathrm{CB}_{2} \mathrm{R}$ tracers. $\mathbf{a}\left[{ }^{11} \mathrm{C}\right] \mathrm{RSR}-056$ on spleen slices from a wild-type $\mathrm{CD} 1 \mathrm{mouse}$. $\mathbf{b}\left[{ }^{11} \mathrm{C}\right] \mathrm{RSR}-056$ on cervical spinal cord from a healthy control and a patient with amyotrophic lateral sclerosis (ALS). c $\left[{ }^{18} \mathrm{~F}\right] \mathrm{RS}-126$ on spleen slices from a Wistar rat. Left: baseline binding; right: blockade with $\mathrm{CB}_{2} \mathrm{R}$ antagonist GW405833

a

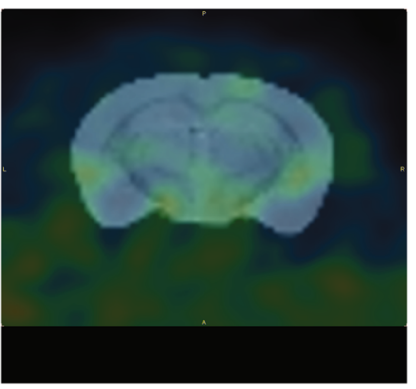

b

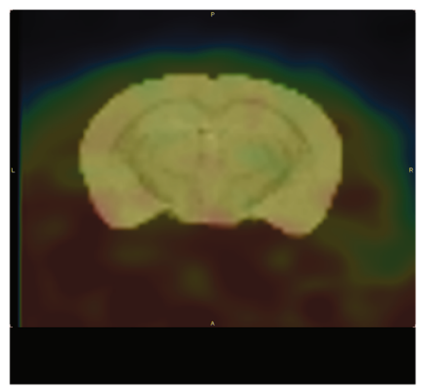

C

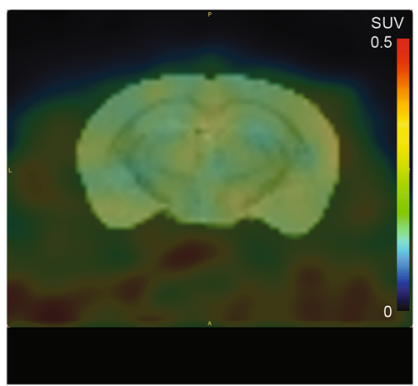

Fig. 3 Representative in vivo microPET images of coronal CD1 mouse brain sections (Bregma $-1.5 \mathrm{~mm} \pm 0.3 \mathrm{~mm}$ ) by averaging dynamic data at 20-60 min after the intravenous injection of $\left[{ }^{11} \mathrm{C}\right] \mathrm{RSR}-056$. a Vehicle-treated mouse. b LPS-treated mouse. c LPS-treated mouse with antagonist GW405833. Scale 0-0.5. SUV standard uptake value

$\mathrm{CB}_{2} \mathrm{R}$ imaging in animal models of multiple sclerosis

$M S$ is an autoimmune inflammatory demyelinating disease [11]. In an experimental autoimmune encephalomyelitis (EAE) model of MS $[64,65]$, activated microglial cells had upregulated $C_{2} R$ at the protein (10-fold) and at mRNA levels (100-fold) compared to ramified microglia. Recent clinical trials on the $\mathrm{CB}_{2} \mathrm{R}$ inhibitor delta (9)-tetrahydrocannabinol in patients with MS showed an ameliorating effect on the symptoms, including perceived spasticity and pain $[66,67]$. Thus, PET tracers for $C_{2} R$ receptors have the potential to detect the pathophysiology of MS and monitor the effects of treatment targeting $\mathrm{CB}_{2} \mathrm{R}$ in MS. However, in the $\mathrm{EAE}$ animal model, a clear disease status is considered difficult to define. Therefore, the EAE animal model might not be an ideal model for the evaluation of $\mathrm{CB}_{2} \mathrm{R}$ tracers.

\section{POTENTIAL CLINICAL USE OF CB $_{2}$ R PET IMAGING OF CNS INFLAMMATION}

Few clinical evaluations of $\mathrm{CB}_{2} \mathrm{R}$ PET imaging have been reported $[45,47]$. The hurdles in $C_{2} R$ tracer development and translation may include: (1) species differences between humans and rodents in their immune systems, microglia subtypes, and levels of $C_{2} R$ expression [68], as well as distinct age-related changes, with a more pro-inflammatory type in humans [69] according to transcriptomic analysis; (2) low expression level of $\mathrm{CB}_{2} \mathrm{R}$ in the brain, even under inflammatory conditions [70]; (3) lack of specific $\mathrm{CB}_{2} \mathrm{R}$ antibody for post-mortem validation of in vivo imaging results [43, 55, 71]; (4) lack of full $\mathrm{CB}_{2} \mathrm{R}$ knock-out mice [72]; and 5) developing a reference region for modeling [73].

$\mathrm{CB}_{2} \mathrm{R}$ imaging in patients with amyotrophic lateral sclerosis ALS is a progressive and fatal motor neuron disease [74]. A variety of genetic factors drive the degeneration of motor neurons and increase the susceptibility to ALS or influence the disease progression rate. $A$ greater density of $\mathrm{CB}_{2} \mathrm{R}$-positive microglia and macrophages was observed in the post-mortem spinal cord tissues from patients with ALS compared to healthy controls. Autoradiography using $\left[{ }^{11} \mathrm{C}\right] \mathrm{RSR}-056$ showed higher and specific binding on the post-mortem spinal cord tissues from patients with ALS compared to that from healthy controls (Fig. 2b). Similar increases were reported in other studies on ASL spinal cord tissues using $\left[{ }^{11} \mathrm{C}\right] \mathrm{RS}-028[31]$ and $\left[{ }^{11} \mathrm{C}\right] \mathrm{KD} 2$ [22].

$\mathrm{CB}_{2} \mathrm{R}$ imaging in patients with Alzheimer's disease

Emerging evidence indicates the involvement of $\mathrm{CB}_{2} \mathrm{R}$ and increased levels of complements, cytokines, and chemokines in the brain of patients with $A D$. Reactive astrocytes, activated microglia, and upregulated $C_{2} R$ were observed in the vicinity of $A \beta$ plaques in post-mortem $A D$ mouse model brains and patients with $A D[62,75-$ 88]. PET using $\left[{ }^{11} \mathrm{C}\right] \mathrm{NE} 40$ showed reduced signal along with $A \beta$ 
deposition visualized by $\left[{ }^{11} \mathrm{C}\right] \mathrm{PIB}$ in $\mathrm{AD}$ patients [47]. Further studies are needed to validate the utility of this tracer. A possible reason for these findings is that $C_{2} R$ upregulation is below the detection threshold, which is evident in the spinal cord from patients with ALS (Fig. 2b). In addition, as CNS inflammation is considered an early event, evaluating patients with mild cognitive impairment at the early stage of the disease process will be informative.

\section{OUTLOOK}

We propose several points for consideration during the development of $C_{2} R$ tracers: (1) Subnanomolar-affinity $C_{2} R$ tracers should be developed, considering the low expression level of the receptor. (2) We should elucidate whether $C_{2} R$ upregulation is disease-stage dependent and relates to a certain type of microglia or astrocyte. (3) Structural optimization to improve the physicochemical and pharmacological properties of this new class of $C_{2} R$ tracer will be necessary. (4) Flow cytometry should be used for surface phenotype characterization, e.g., CD45 and CD11 positivity and differentiating pro- and anti-inflammatory microglial subtypes and astrocytes. (5) Imaging results using $\mathrm{CB}_{2} \mathrm{R}$ and TSPO tracers should be compared head to head. Given that $\mathrm{CB}_{2} \mathrm{R}$ more closely represents anti-inflammatory features, additional knowledge of the inflammatory status in the CNS will be provided by PET imaging using both $\mathrm{CB}_{2} \mathrm{R}$ and TSPO tracers [43]. (6) The mRNA expression of $C_{2} R$ should be measured. (7) Rational translation evaluation processes will be vital. Mouse and rat models of cerebral ischemia at 4-5 days after reperfusion might be a suitable model to test and validate $\mathrm{CB}_{2} \mathrm{R}$ tracers.

$\mathrm{CB}_{2} \mathrm{R}$ is also expressed on activated immune cells outside the CNS which represent potential targets for $C_{2} R$ PET imaging. Recent $\mathrm{CB}_{2} \mathrm{R}$ imaging using $\left[{ }^{11} \mathrm{C}\right] \mathrm{RS}-016$ shows the detection of vascular inflammation in the post-mortem carotid plaque from humans and mouse models of atherosclerosis [30].

\section{CONCLUSION}

$\mathrm{CB}_{2} \mathrm{R}$ PET ligands will serve as useful tools for tracking the in vivo alterations in CNS inflammation during the progression of these disorders and for understanding the disease mechanisms. $\mathrm{CB}_{2} \mathrm{R}$ PET ligands will also help illuminate new treatment strategies for neurological disorders in which CNS inflammation is implicated.

\section{ACKNOWLEDGEMENTS}

This work was partly funded by the University of Zurich and the ETH Zurich Foundation through a Seed Grant of "University Medicine Zurich/Hochschulmedizin Zürich" and University of Zurich grant "Forschungskredit (Nr. FK-17-052)".

\section{ADDITIONAL INFORMATION}

Competing interests: The authors declare no conflicts of interest.

Publisher's note: Springer Nature remains neutral with regard to jurisdictional claims in published maps and institutional affiliations.

\section{REFERENCES}

1. Stempel AV, Stumpf A, Zhang HY, Ozdogan T, Pannasch U, Theis AK, et al. Cannabinoid type 2 receptors mediate a cell type-specific plasticity in the hippocampus. Neuron. 2016;90:795-809.

2. Di Marzo V, Stella N, Zimmer A. Endocannabinoid signalling and the deteriorating brain. Nat Rev Neurosci. 2015;16:30-42.

3. Van Sickle MD, Duncan M, Kingsley PJ, Mouihate A, Urbani P, Mackie K, et al. Identification and functional characterization of brainstem cannabinoid CB2 receptors. Science. 2005;310:329-332.

4. Xi ZX, Peng XQ, Li X, Song R, Zhang HY, Liu QR, et al. Brain cannabinoid $C B(2)$ receptors modulate cocaine's actions in mice. Nat Neurosci. 2011;14:1160-6.
5. Zhang HY, Gao M, Liu QR, Bi GH, Li X, Yang HJ, et al. Cannabinoid CB2 receptors modulate midbrain dopamine neuronal activity and dopamine-related behavior in mice. Proc Natl Acad Sci USA. 2014;111:E5007-E5015.

6. Benito C, Tolón RM, Pazos MR. Cannabinoid CB2 receptors in human brain inflammation. Br J Pharmacol. 2008;153:277-85.

7. Heneka MT, Golenbock DT, Latz E. Innate immunity in Alzheimer's disease [Review]. Nat Immunol. 2015;16:229-36.

8. Graeber MB, Li W, Rodriguez ML. Role of microglia in CNS inflammation. FEBS Lett. 2011;585:3798-805.

9. Hirsch EC, Hunot S. Neuroinflammation in Parkinson's disease: a target for neuroprotection? Lancet Neurol. 2009;8:382-97.

10. Philips $T$, Robberecht W. Neuroinflammation in amyotrophic lateral sclerosis: role of glial activation in motor neuron disease. Lancet Neurol. 2011;10:253-63.

11. Frischer JM, Bramow S, Dal-Bianco A, Lucchinetti CF, Rauschka H, Schmidbauer M, et al. The relation between inflammation and neurodegeneration in multiple sclerosis brains. Brain. 2009;132:1175-89.

12. Crotti A, Glass CK. The choreography of neuroinflammation in Huntington's disease. Trends Immunol. 2015;36:364-73.

13. Rupprecht R, Papadopoulos V, Rammes G, Baghai TC, Fan J, Akula N, et al. Translocator protein (18 kDa) (TSPO) as a therapeutic target for neurological and psychiatric disorders. Nat Rev Drug Discov. 2010;9:971-88.

14. Owen DR, Yeo AJ, Gunn RN, Song K, Wadsworth G, Lewis A, et al. An 18-kDa Translocator Protein (TSPO) polymorphism explains differences in binding affinity of the PET radioligand PBR28. J Cereb Blood Flow Metab. 2011;32:1-5.

15. Hamelin L, Lagarde J, Dorothee G, Leroy C, Labit M, Comley RA, et al. Early and protective microglial activation in Alzheimer's disease: a prospective study using 18F-DPA-714 PET imaging. Brain. 2016;139:1252-64.

16. Ikawa M, Lohith TG, Shrestha S, Telu S, Zoghbi SS, Castellano S, et al. 11C-ER176, a radioligand for $18-\mathrm{kDa}$ translocator protein, has adequate sensitivity to robustly image all three affinity genotypes in human brain. J Nucl Med. 2017;58:320-5.

17. Jacobs $\mathrm{AH}$, Tavitian B. Noninvasive molecular imaging of neuroinflammation. J Cereb Blood Flow Metab. 2012;32:1393-415.

18. Dupont AC, Largeau B, Santiago Ribeiro MJ, Guilloteau D, Tronel C, Arlicot N. Translocator protein-18 kDa (TSPO) Positron Emission Tomography (PET) imaging and its clinical impact in neurodegenerative diseases. Int J Mol Sci. 2017;18:785.

19. Kreisl WC, Lyoo CH, McGwier M, Snow J, Jenko KJ, Kimura N, et al. In vivo radioligand binding to translocator protein correlates with severity of Alzheimer's disease. Brain. 2013;136:2228-38.

20. Rodriguez-Vieitez E, Ni R, Gulyas B, Toth M, Haggkvist J, Halldin C, et al. Astrocytosis precedes amyloid plaque deposition in Alzheimer APPswe transgenic mouse brain: a correlative positron emission tomography and in vitro imaging study. Eur J Nucl Med Mol Imaging. 2015;42:1119-32.

21. Varley J, Brooks DJ, Edison P. Imaging neuroinflammation in Alzheimer's and other dementias: Recent advances and future directions. Alzheimers Dement. 2015;11:1110-20.

22. Mu L, Bieri D, Slavik R, Drandarov K, Muller A, Cermak $S$, et al. Radiolabeling and in vitro /in vivo evaluation of $\mathrm{N}$-(1-adamantyl)-8-methoxy-4-oxo-1-phenyl-1,4dihydroquinoline-3-carboxamide as a PET probe for imaging cannabinoid type 2 receptor. J Neurochem. 2013;126:616-24.

23. Mu L, Slavik R, Muller A, Popaj K, Cermak S, Weber M, et al. Synthesis and preliminary evaluation of a 2-oxoquinoline carboxylic acid derivative for PET imaging the cannabinoid type 2 receptor. Pharm (Basel). 2014;7:339-52.

24. Yrjola S, Sarparanta M, Airaksinen AJ, Hytti M, Kauppinen A, Pasonen-Seppanen S, et al. Synthesis, in vitro and in vivo evaluation of 1,3,5-triazines as cannabinoid CB2 receptor agonists. Eur J Pharm Sci. 2015;67:85-96.

25. Slavik R, Herde AM, Bieri D, Weber M, Schibli R, Kramer SD, et al. Synthesis, radiolabeling and evaluation of novel 4-oxo-quinoline derivatives as PET tracers for imaging cannabinoid type 2 receptor. Eur J Med Chem. 2015;92:554-64.

26. Slavik R, Grether U, Muller Herde A, Gobbi L, Fingerle J, Ullmer C, et al. Discovery of a high affinity and selective pyridine analog as a potential positron emission tomography imaging agent for cannabinoid type 2 receptor. J Med Chem. 2015;58:4266-77.

27. Slavik R, Bieri D, Cermak S, Muller A, Kramer SD, Weber M, et al. Development and evaluation of novel PET tracers for imaging cannabinoid receptor type 2 in brain. Chim (Aarau). 2014;68:208-10.

28. Slavik R, Muller Herde A, Haider A, Kramer SD, Weber M, Schibli R, et al. Discovery of a fluorinated 4-oxo-quinoline derivative as a potential positron emission tomography radiotracer for imaging cannabinoid receptor type 2. J Neurochem. 2016;138:874-86.

29. Haider A, Muller Herde A, Slavik R, Weber M, Mugnaini C, Ligresti A, et al. Synthesis and biological evaluation of thiophene-based cannabinoid receptor type 2 radiotracers for PET imaging. Front Neurosci. 2016;10:350.

30. Meletta R, Slavik R, Mu L, Rancic Z, Borel N, Schibli R, et al. Cannabinoid receptor type 2 (CB2) as one of the candidate genes in human carotid plaque 
imaging: Evaluation of the novel radiotracer $\left[{ }^{11} \mathrm{C}\right] \mathrm{RS}-016$ targeting $\mathrm{CB} 2$ in atherosclerosis. Nucl Med Biol. 2017;47:31-43.

31. Haider A, Spinelli F, Herde AM, Mu B, Keller C, Margelisch M, et al. Evaluation of 4oxo-quinoline-based CB2 PET radioligands in R6/2 chorea huntington mouse model and human ALS spinal cord tissue. Eur J Med Chem. 2018;145: 746-59.

32. Postnov A, Ahmad R, Evens N. Quantification of ${ }^{11} \mathrm{C}-\mathrm{NE} 40$, a novel PET radioligand for CB2 receptor imaging. J Nucl Med. 2013;54:2101-3.

33. Horti AG, Gao Y, Ravert HT, Finley P, Valentine H, Wong DF, et al. Synthesis and biodistribution of $\left[{ }^{11} \mathrm{C}\right] \mathrm{A}-836339$, a new potential radioligand for PET imaging of cannabinoid type 2 receptors (CB2). Bioorg Med Chem. 2010;18:5202-7.

34. Pottier G, Gomez-Vallejo V, Padro D, Boisgard R, Dolle F, Llop J, et al. PET imaging of cannabinoid type 2 receptors with $\left[{ }^{11} \mathrm{C}\right] \mathrm{A}-836339$ did not evidence changes following neuroinflammation in rats. J Cereb Blood Flow Metab. 2017;37:1163-78.

35. Moldovan R-P, Deuther-Conrad W, Teodoro R, Wang Y, Fischer S, Pomper M, et al. 18F-JHU94620, a high affinity PET radioligand for imaging of cannabinoid subtype 2 receptors (CB2R). J Nucl Med. 2015;56(supplement 3):1048-1048.

36. Moldovan RP, Teodoro R, Gao Y, Deuther-Conrad W, Kranz M, Wang Y, et al. Development of a high-Affinity PET radioligand for imaging cannabinoid subtype 2 receptor. J Med Chem. 2016;59:7840-55.

37. Moldovan RP, Hausmann K, Deuther-Conrad W, Brust P. Development of highly affine and selective fluorinated cannabinoid type 2 receptor ligands. ACS Med Chem Lett. 2017;8:566-71.

38. Ahamed M, van Veghel D, Ullmer C, Van Laere K, Verbruggen A, Bormans GM. Synthesis, biodistribution and in vitro evaluation of brain permeable high affinity type 2 cannabinoid receptor agonists $\left[{ }^{11} \mathrm{C}\right] \mathrm{MA} 2$ and $\left[{ }^{18} \mathrm{~F}\right] \mathrm{MA} 3$. Front Neurosci. 2016;10:431.

39. Caill Ã F, Cacheux F, Peyronneau M-A, Jaumain E, Pottier G, Ullmer C, et al. Biodistribution of $\left[{ }^{18} \mathrm{~F}\right] \mathrm{FC} 0324$, a new PET tracer targeting $\mathrm{CB} 2$ receptors. J Nucl Med. 2017;58:855.

40. Spinelli F, Mu L, Ametamey SM. Radioligands for positron emission tomography imaging of cannabinoid type 2 receptor. J Label Comp Radiopharm. 2018;61: 299-308.

41. Caille F, Cacheux F, Peyronneau MA, Jego B, Jaumain E, Pottier G, et al. From structure-activity relationships on thiazole derivatives to the in vivo evaluation of a new radiotracer for cannabinoid subtype 2 PET imaging. Mol Pharm. 2017;14:4064-78.

42. Evens N, Vandeputte C, Coolen C, Janssen P, Sciot R, Baekelandt V, et al. Preclinical evaluation of $\left[{ }^{11} \mathrm{C}\right] \mathrm{NE} 40$, a type 2 cannabinoid receptor PET tracer. Nucl Med Biol. 2012;39:389-99.

43. Hosoya T, Fukumoto $D$, Kakiuchi T, Nishiyama $S$, Yamamoto $S$, Ohba $H$, et al. In vivo TSPO and cannabinoid receptor type 2 availability early in post-stroke neuroinflammation in rats: a positron emission tomography study. J Neuroinflamm. 2017;14:69.

44. Rühl T, Deuther-Conrad W, Fischer S, Günther R, Hennig L, Krautscheid H, et al. Cannabinoid receptor type 2 (CB2)-selective $\mathrm{N}$-aryl-oxadiazolyl-propionamides: synthesis, radiolabelling, molecular modelling and biological evaluation. Org Med Chem Lett. 2012;2:32.

45. Ahmad R, Koole M, Evens N, Serdons K, Verbruggen A, Bormans G, et al. Wholebody biodistribution and radiation dosimetry of the cannabinoid type 2 receptor ligand $\left[{ }^{11} \mathrm{C}\right]-\mathrm{NE} 40$ in healthy subjects. Mol Imaging Biol. 2013;15:384-90.

46. Vandeputte C, Casteels C, Struys T, Koole M, van Veghel D, Evens N, et al. Smallanimal PET imaging of the type 1 and type 2 cannabinoid receptors in a photothrombotic stroke model. Eur J Nucl Med Mol Imaging. 2012;39:1796-806.

47. Ahmad R, Postnov A, Bormans G, Versijpt J, Vandenbulcke M, Van Laere K. Decreased in vivo availability of the cannabinoid type 2 receptor in Alzheimer's disease. Eur J Nucl Med Mol Imaging. 2016:43:2219-27.

48. Vandeputte C, Casteels C, Struys T, Koole M, van Veghel D, Evens N, et al. Smallanimal PET imaging of the type 1 and type 2 cannabinoid receptors in a photothrombotic stroke model. Eur J Nucl Med Mol Imaging. 2012;39:1796-806.

49. Gao M, Wang M, Miller KD, Hutchins GD, Zheng QH. Synthesis and in vitro biological evaluation of carbon-11-labeled quinoline derivatives as new candidate PET radioligands for cannabinoid CB2 receptor imaging. Bioorg Med Chem. 2010;18:2099-106.

50. Evens N, Vandeputte C, Muccioli GG, Lambert DM, Baekelandt V, Verbruggen AM, et al. Synthesis, in vitro and in vivo evaluation of fluorine-18 labelled FE-GW405833 as a PET tracer for type 2 cannabinoid receptor imaging. Bioorg Med Chem. 2011;19:4499-505.

51. Evens N, Bosier B, Lavey BJ, Kozlowski JA, Vermaelen P, Baudemprez L, et al. Labelling and biological evaluation of $\left[{ }^{11} \mathrm{C}\right]$ methoxy-Sch225336: a radioligand for the cannabinoid-type 2 receptor. Nucl Med Biol. 2008;35:793-800.

52. Teodoro R, Moldovan RP, Lueg C, Gunther R, Donat CK, Ludwig FA, et al. Radiofluorination and biological evaluation of $\mathrm{N}$-aryl-oxadiazolyl-propionamides as potential radioligands for PET imaging of cannabinoid CB2 receptors. Org Med Chem Lett. 2013;3:11.
53. Bertini S, Parkkari T, Savinainen JR, Arena C, Saccomanni G, Saguto S, et al. Synthesis, biological activity and molecular modeling of new biphenylic carboxamides as potent and selective CB2 receptor ligands. Eur J Med Chem. 2015;90:526-36.

54. Yu SJ, Reiner D, Shen H, Wu KJ, Liu QR, Wang Y. Time-dependent protection of CB2 receptor agonist in stroke. PLoS ONE. 2015;10:e0132487.

55. England TJ, Hind WH, Rasid NA, O'Sullivan SE. Cannabinoids in experimental stroke: a systematic review and meta-analysis. J Cereb Blood Flow Metab. 2015;35:348-58

56. Bravo-Ferrer I, Cuartero MI, Zarruk JG, Pradillo JM, Hurtado O, Romera VG, et al. Cannabinoid type-2 receptor drives neurogenesis and improves functional outcome after stroke. Stroke. 2017;48:204-12.

57. Ronca RD, Myers AM, Ganea D, Tuma RF, Walker EA, Ward SJ. A selective cannabinoid $C B 2$ agonist attenuates damage and improves memory retention following stroke in mice. Life Sci. 2015;138:72-7.

58. Zarruk JG, Fernandez-Lopez D, Garcia-Yebenes I, Garcia-Gutierrez MS, Vivancos J, Nombela F, et al. Cannabinoid type 2 receptor activation downregulates strokeinduced classic and alternative brain macrophage/microglial activation concomitant to neuroprotection. Stroke. 2012;43:211-9.

59. Zhang M, Martin BR, Adler MW, Razdan RK, Jallo Jl, Tuma RF. Cannabinoid CB(2) receptor activation decreases cerebral infarction in a mouse focal ischemia/ reperfusion model. J Cereb Blood Flow Metab. 2007;27:1387-96.

60. Perry $\mathrm{VH}$, Holmes C. Microglial priming in neurodegenerative disease. Nat Rev Neurol. 2014;10:217-24.

61. Savonenko AV, Melnikova T, Wang Y, Ravert H, Gao Y, Koppel J et al. Cannabinoid $C B 2$ receptors in a mouse model of $A \beta$ amyloidosis: immunohistochemical analysis and suitability as a PET biomarker of neuroinflammation. PloS ONE. 2015;10:e0129618.

62. Aso E, Juves S, Maldonado R, Ferrer I. CB2 cannabinoid receptor agonist ameliorates Alzheimer-like phenotype in AßPP/PS1 mice. J Alzheimers Dis. 2013;35:847-58

63. Wu J, Bie B, Yang $\mathrm{H}, \mathrm{Xu} \mathrm{JJ}$, Brown DL, Naguib M. Activation of the CB2 receptor system reverses amyloid-induced memory deficiency. Neurobiol Aging. 2013;34:791-804.

64. Maresz K, Carrier EJ, Ponomarev ED, Hillard CJ, Dittel BN. Modulation of the cannabinoid CB2 receptor in microglial cells in response to inflammatory stimuli. J Neurochem. 2005;95:437-45.

65. Zrzavy T, Hametner S, Wimmer I, Butovsky O, Weiner HL, Lassmann H. Loss of 'homeostatic' microglia and patterns of their activation in active multiple sclerosis. Brain. 2017:140:1900-13.

66. Zajicek J, Ball S, Wright D, Vickery J, Nunn A, Miller D, et al. Effect of dronabinol on progression in progressive multiple sclerosis (CUPID): a randomised, placebocontrolled trial. Lancet Neurol. 2013;12:857-65.

67. Palazuelos J, Davoust N, Julien B, Hatterer E, Aguado T, Mechoulam R, et al. The $\mathrm{CB}(2)$ cannabinoid receptor controls myeloid progenitor trafficking: involvement in the pathogenesis of an animal model of multiple sclerosis. J Biol Chem. 2008;283:13320-9.

68. Smith AM, Dragunow M. The human side of microglia. Trends Neurosci. 2014;37:125-35.

69. Galatro TF, Holtman IR, Lerario AM, Vainchtein ID, Brouwer N, Sola PR, et al. Transcriptomic analysis of purified human cortical microglia reveals ageassociated changes. Nat Neurosci. 2017;20:1162-71.

70. Chen DJ, Gao M, Gao FF, Su QX, Wu J. Brain cannabinoid receptor 2: expression, function and modulation. Acta Pharmacol Sin. 2017;38:312-6.

71. Nagayama T, Sinor AD, Simon RP, Chen J, Graham SH, Jin K, et al. Cannabinoids and neuroprotection in global and focal cerebral ischemia and in neuronal cultures. J Neurosci. 1999;19:2987-95.

72. Constantinescu CS, Farooqi N, O'Brien K, Gran B. Experimental autoimmune encephalomyelitis (EAE) as a model for multiple sclerosis (MS). $\mathrm{Br} J$ Pharmacol. 2011;164:1079-106.

73. Li Y, Kim J. Neuronal expression of CB2 cannabinoid receptor mRNAs in the mouse hippocampus. Neuroscience 2015;311:253-67.

74. Taylor JP, Brown RH Jr, Cleveland DW. Decoding ALS: from genes to mechanism. Nature. 2016:539:197-206.

75. Solas M, Francis PT, Franco R, Ramirez MJ. CB2 receptor and amyloid pathology in frontal cortex of Alzheimer's disease patients. Neurobiol Aging. 2013;34:805-8.

76. Schmole AC, Lundt R, Ternes S, Albayram O, Ulas T, Schultze JL, et al. Cannabinoid receptor 2 deficiency results in reduced neuroinflammation in an Alzheimer's disease mouse model. Neurobiol Aging. 2015;36:710-9.

77. Wu J, Hocevar M, Foss JF, Bie B, Naguib M. Activation of CB2 receptor system restores cognitive capacity and hippocampal Sox 2 expression in a transgenic mouse model of Alzheimer's disease. Eur J Pharmacol. 2017;811:12-20.

78. Koppel J, Vingtdeux V, Marambaud $P$, d'Abramo $C$, Jimenez $H$, Stauber $M$, et al. $\mathrm{CB} 2$ receptor deficiency increases amyloid pathology and alters tau processing in a transgenic mouse model of Alzheimer's disease. Mol Med. 2014;20:29-36. 
79. Kofalvi A, Lemos C, Martin-Moreno AM, Pinheiro BS, Garcia-Garcia L, Pozo MA et al. Stimulation of brain glucose uptake by cannabinoid CB2 receptors and its therapeutic potential in Alzheimer's disease. Neuropharmacology. 2016;110: 519-29.

80. Jayant S, Sharma BM, Bansal R, Sharma B. Pharmacological benefits of selective modulation of cannabinoid receptor type 2 (CB2) in experimental Alzheimer's disease. Pharmacol Biochem Behav. 2016;140:39-50.

81. Aso E, Andres-Benito P, Carmona M, Maldonado R, Ferrer I. Cannabinoid receptor 2 participates in amyloid-beta processing in a mouse model of Alzheimer's disease but plays a minor role in the therapeutic properties of a cannabis-based medicine. J Alzheimers Dis. 2016:51:489-500.

82. Benito C, Nunez E, Tolon RM, Carrier EJ, Rabano A, Hillard CJ, et al. Cannabinoid CB2 receptors and fatty acid amide hydrolase are selectively overexpressed in neuritic plaque-associated glia in Alzheimer's disease brains. J Neurosci. 2003;23:11136-41.

83. Glass CK, Saijo K, Winner B, Marchetto MC, Gage FH. Mechanisms underlying inflammation in neurodegeneration. Cell. 2010;140:918-34.
84. Fuger P, Hefendehl JK, Veeraraghavalu K, Wendeln AC, Schlosser C, Obermuller U, et al. Microglia turnover with aging and in an Alzheimer's model via long-term in vivo single-cell imaging. Nat Neurosci. 2017;20:1371-6.

85. Cagnin A, Brooks D, Kennedy A, Gunn R, Myers R, Turkheimer F, et al. In-vivo measurement of activated microglia in dementia. Lancet. 2001;358:461-7.

86. Martin-Moreno AM, Brera B, Spuch C, Carro E, Garcia-Garcia L, Delgado M, et al. Prolonged oral cannabinoid administration prevents neuroinflammation, lowers beta-amyloid levels and improves cognitive performance in Tg APP 2576 mice. J Neuroinflamm. 2012;9:8.

87. Saccomanni G, Pascali G, Carlo SD, Panetta D, De Simone M, Bertini S, et al. Design, synthesis and preliminary evaluation of (18)F-labelled 1,8-naphthyridinand quinolin-2-one-3-carboxamide derivatives for PET imaging of CB2 cannabinoid receptor. Bioorg Med Chem Lett. 2015;25:2532-5.

88. Ramirez BG, Blazquez C, Gomez del Pulgar T, Guzman M, de Ceballos ML. Prevention of Alzheimer's disease pathology by cannabinoids: neuroprotection mediated by blockade of microglial activation. J Neurosci. 2005;25:1904-13. 